\title{
Malignancies after pediatric kidney transplantation: more than PTLD?
}

\author{
Martin Mynarek • Kais Hussein • Hans H. Kreipe • \\ Britta Maecker-Kolhoff
}

Received: 29 May 2013 /Revised: 9 August 2013 /Accepted: 23 August 2013 /Published online: 24 September 2013

(C) IPNA 2013

\begin{abstract}
Post-transplant lymphoproliferative disease (PTLD) is the most frequent malignant complication of transplantation in childhood. Even with modern post-transplant immunosuppressive strategies, $1-2 \%$ of all kidney transplant recipients will develop PTLD within the first 5 years after transplantation, and the risk remains high even thereafter as long as immunosuppression is required. In addition to PTLD, adult kidney transplant recipients have an increased incidence of other immunosuppression-related malignancies, such as nonmelanoma skin cancer or Kaposi's sarcoma. It is foreseeable that pediatric transplant recipients will face similar complications during their adult life. Not only immunosuppression but also other risk factors have been identified for some of these malignancies. Strategies addressing these risk factors during childhood may contribute to life-long cancer prevention. Furthermore, early recognition and regular screening may facilitate early diagnosis and treatment, thereby reducing transplant-related morbidity. In this review we focus on malignant complications after renal transplantation and discuss known risk factors. We also review current screening strategies for malignancies during post-transplant follow-up.
\end{abstract}

M. Mynarek • B. Maecker-Kolhoff $(\bowtie)$

Department of Pediatric Haematology and Oncology, Hannover

Medical School, Carl-Neuberg-Str. 1, 30625 Hannover, Germany

e-mail: maecker.britta@mh-hannover.de

URL: www.mh-hannover.de

M. Mynarek · B. Maecker-Kolhoff

Integrated Research and Treatment Centre Transplantation,

Hannover Medical School, Hannover, Germany

K. Hussein • H. H. Kreipe

Institute of Pathology, Hannover Medical School,

Hannover, Germany
Keywords Kidney transplantation · Transplantation · Post-transplant lymphoproliferative disease $\cdot$ Post-transplant lymphoproliferative disease $\cdot$ Screening $\cdot$ Cancer

$\begin{array}{ll}\text { Abbreviations } \\ \text { AIDS } & \text { Acquired immunodeficiency syndrome } \\ \text { BCC } & \text { Basal cell carcinoma } \\ \text { CSA } & \text { Cyclosporine A } \\ \text { DLBCL } & \text { Diffuse large B cell lymphoma } \\ \text { EBV } & \text { Epstein-Barr virus } \\ \text { HBV } & \text { Hepatitis B virus } \\ \text { HCV } & \text { Hepatitis C virus } \\ \text { HPV } & \text { Human papilloma virus } \\ \text { KS } & \text { Kaposi's sarcoma } \\ \text { KTx } & \text { Kidney transplantation } \\ \text { LTx } & \text { Liver transplantation } \\ \text { MMF } & \text { Mycophenolate mofetil } \\ \text { NHL } & \text { Non-Hodgkin's lymphoma } \\ \text { PT-KS } & \text { Post-transplant Kaposi's sarcoma } \\ \text { PTLD } & \text { Post-transplant lymphoproliferative disease } \\ \text { PTSMT } & \text { Post-transplant smooth muscle tumor } \\ \text { RCC } & \text { Renal cell carcinoma } \\ \text { RI } & \text { Reduction of immunosuppression } \\ \text { SCC } & \text { Squamous cell carcinoma } \\ \text { SOT } & \text { Solid organ transplantation }\end{array}$

Introduction

Kidney transplantation (KTx) is the preferred treatment option for children with end-stage renal disease. More than 10,000 pediatric KTx procedures have been performed in the last 20 years in the USA alone [1], and long-term patient survival to date exceeds $80 \%$ at 10 years post-transplantation [2]. The risk of cancer development is higher in KTx recipients than in 
the general population, with incidences beginning to rise early after KTx and continuing to increase with both age and time after transplantation [3]. Therefore, cancer is likely to significantly contribute to morbidity in long-term survivors of KTx, making prevention and early diagnosis of cancer a pivotal issue during long-term follow-up.

\section{Cancer after pediatric solid organ transplantation}

Today, approximately $11 \%$ of all deaths after pediatric KTx are related to cancer [1]. With improved graft survival and overall survival, this proportion is likely to rise. Moreover, pediatric solid organ transplantation (SOT) recipients are at increased chance to reach an age at which "adult" types of cancer become relevant. Therefore, the spectrum of cancers observed in former pediatric SOT recipients will change with their age, and important conclusions regarding the potential for cancer in pediatric SOT recipients may be drawn from studies including large proportions of adult patients. During childhood and adolescence, the vast majority of cancers after transplantation are post-transplant lymphoproliferative diseases (PTLD) [4], while pediatric SOT recipients who have reached adulthood will be at high risk for other-mainly epithelium-derived - cancers in their adult life.

In this review we summarize the current knowledge on malignant diseases after pediatric KTx and discuss the implications of reports on cancer after SOT in adults.

\section{Population-based approaches towards cancer risk after SOT}

Various studies have recently focused on elucidating the cancer risk after SOT. In general, these studies used populationbased approaches, linking local transplant registries to cancer registries and subsequently analyzing post-transplant cancer incidences for more than 250,000 SOT recipients [3-7]. The results of these studies demonstrate an approximately twofold higher overall cancer risk in SOT recipients compared to the general population. This excess risk was not homogenous among all cancer types and found to be especially high in cancers with an infection-related pathogenesis, such as PTLD, Kaposi's sarcoma (KS), liver cancer, and human papilloma virus (HPV)-related epithelial cancers (cancer of cervix uteri, anal, vaginal or penile cancers). Helicobacter pylori-associated gastric cancer was also found to be more frequent in transplanted individuals than in the general population.

Among cancers with no or uncertain viral association, the incidences of skin and lip cancers were most prominently elevated, with transplant recipients having a greater than a tenfold increased risk $[3,5-10]$. The risk for kidney and lung cancer was also elevated after SOT. Although the increased risk was most notable after transplantation of the corresponding organ, an increased risk for both cancer types was seen in all types of SOT [3].

\section{Cancer related to infectious pathogens}

Post-transplant lymphoproliferative disease

Post-transplant lymphoproliferative disease is the most frequent early (i.e. within 10 years after transplantation) malignant complication after pediatric KTx [1, 3, 7]. Its 5-year incidence is $1-2 \%$, which is lower than the incidences in other SOT types. For example, pediatric lung or small bowel transplant recipients have a risk of developing PTLD within the first 5 years after transplantation of up to $15 \%$ [11-13].

PTLD incidence has a bimodal distribution in pediatric SOT recipients. The first peak is within the first year after transplantation ("early PTLD") and the second is within the third year [14].

\section{Pathophysiology}

Infection with Epstein-Barr virus (EBV) plays a major role in the development of PTLD. EBV infects B cells and subsequently induces these cells to undergo malignant transformation. In immune competent individuals, primary infection with EBV induces strong T cell responses, which prevent the outgrowth of malignant clones [15]. This response is impaired by transplantassociated immunosuppression, hereby predisposing patients to EBV-related malignancies. However, EBV infection alone is not sufficient to induce PTLD [16], and other factors have been discussed. To date, however, no definite role for these other factors in lymphomagenesis has been identified.

\section{Risk factors of PTLD development}

Epstein-Barr virus and to a lesser extent cytomegalovirus (CMV) serostatus at transplantation are major risk factors for PTLD. EBV-seronegative patients have a fourfold increased risk of developing PTLD compared to EBV-seropositive recipients. CMV seronegativity increases the PTLD risk by a factor of two, presumably due to crossreactivity of the antibodies. However, this effect is less consistent between studies [17-19]. Furthermore, age at transplantation is correlated with the incidence of PTLD: children are usually considered to be at higher risk than adolescents [17, 20,21], which may be attributed to EBV serostatus at transplantation. In a large pediatric cohort, complete HLA-DR mismatch between graft and recipient was significantly associated with more frequent PTLD development [22]. 
While the impact of immunosuppression on PTLD pathogenesis is unquestioned, the role of individual drugs is difficult to determine. Most data are derived from retrospective studies in adult SOT recipients. Some of these suggest a slightly increased risk for PTLD in patients who receive immunosuppressive maintenance with tacrolimus compared to cyclosporine A (CSA), while others do not find a difference $[18,20,23]$. Inclusion of mycophenolate mofetil (MMF) in a calcineurin inhibitor-based regimen does not increase the risk of PTLD [24-26]. Belatacept increased PTLD incidence in several phase II/III trials in adult KTx [27].

Induction therapy with the anti-T cell antibodies thymoglobulin and OKT3 was associated with an increased risk of PTLD [20, 28-30]. As a result, OKT3 has been removed from current protocols in KTx and thymoglobulin is usually used in lower doses than previously. Other monocolonal antibodies used for tolerance induction, such as anti-interleukin (IL)-2 receptor antibodies (e.g. basiliximab) or alemtuzumab, do not seem to have this association [31,32].

\section{Histology/classification}

Every lymphoid malignancy arising after transplantation is usually classified as "PTLD". The 2008 World Health Organization classification for lymphoid malignancies [33] separates PTLD into four major categories: early lesions, polymorphic PTLD, monomorphic PTLD and Hodgkin PTLD.

Early lesions and polymorphic PTLD are polyclonal lymphoproliferations that do not resemble the histology of classical malignant lymphoma, but they may show similar biological characteristics. The histology of monomorphic PTLD resembles that of classical malignant lymphoma. Most monomorphic PTLD are of B cell origin, with diffuse large B cell lymphoma (DLBCL) being the most frequent subtype in children (Fig. 1a). Classical Hodgkin PTLD and T cell non-Hodgkin's lymphoma (T-NHL) are rare PTLD subtypes.

\section{Treatment}

Reduction of immunosuppressive drugs (RI) may partly restore immune responses and hereby induce complete remission in up to $50 \%$ of the patients [34]. Although balancing immune reconstitution versus the risk of graft rejection is challenging, current guidelines recommend RI as first-line therapy wherever possible [35]. Furthermore, a change in the immunosuppressive regimen towards an mTOR-based regimen may be considered due to the drug's suspected antitumor activity.

If RI is deemed impossible or insufficient, further therapy is required. The monoclonal anti-CD20 antibody rituximab is used routinely for all CD20-positive PTLD with very promising results, either in combination with cytotoxic chemotherapy [36] or used as monotherapy (unpublished results of the German Ped-PTLD 2005 Pilot trial, BMK). Patients refractory to rituximab in combination with mild chemotherapy, patients with central nervous system involvement or patients with rare PTLD subtypes, such as T-NHL or Hodgkin's disease, require individualized treatment.

Detection of EBV gene products in the majority of pediatric PTLD provides an attractive target for anti-tumor immunotherapy. EBV-specific T cells can be manufactured from autologous or third-party donors, an approach that is currently being evaluated in several clinical trials (for a recent review see Bollard et al [37]).

\section{Prognosis}

In a recent prospective study for pediatric PTLD, 2-year overall survival was $83 \%$ [36], while in retrospective series of unselected patients 2-year overall survival was around $70 \%$ $[38,39]$. A more detailed summary of published prognostic factors is compiled in Table 1.

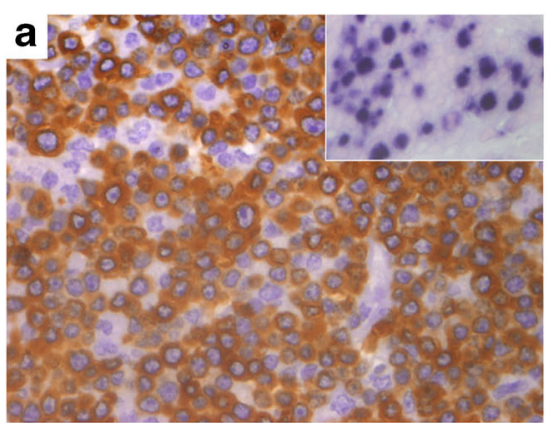

Fig. 1 Epstein-Barr virus (EBV)-associated post-transplant neoplasms. a High-grade monomorphic B cell post-transplant lymphoproliferative disease (PTLD) with CD79a-positive plasmoblastic differentiation, prominent nucleoli and nuclear positivity for EBV-encoded small RNA [EBV-encoded small RNA (EBER) in situ hybridization; insert]. In this

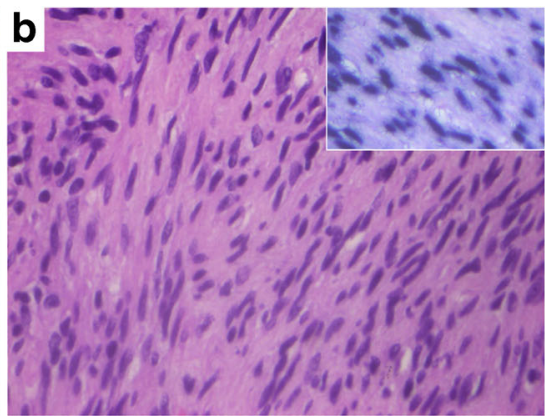

child, the PTLD manifested 7 years after renal transplantation (RTx) in a cervical lymph node. b Rare PTSMT are characterized by proliferation of spindle cells with smooth muscle phenotype and infection of tumor cells by EBV (hematoxylin and eosin stain; EBER, inset). Original magnification in all images: $\times 400$ 
Table 1 Risk factors for development of post-transplant lymphoproliferative disease and prognostic factors

\begin{tabular}{|c|c|c|}
\hline $\begin{array}{l}\text { Risk factors for PTLD development } \\
\text { after transplantation }\end{array}$ & Description & Reference \\
\hline Age & PTLD more frequent in younger children & \\
\hline Transplanted organ & $\begin{array}{l}\text { PTLD incidences in decreasing order } \\
\text { 1. Intestinal transplantation (approx. } 20 \% \text { ) } \\
\text { 2. Lung transplantation (approx. } 15 \% \text { ) } \\
\text { 3. Liver transplantation (approx. 5-10\%) } \\
\text { 4. Heart transplantation (approx. } 6 \% \text { ) } \\
\text { 5. Renal transplantation (approx. } 2-3 \% \text { ) }\end{array}$ & $\begin{array}{l}{[13]} \\
{[12]} \\
{[89]} \\
{[18]} \\
{[21]}\end{array}$ \\
\hline Epstein-Barr virus (EBV) status & Higher PTLD incidence in seronegative patients at transplantation & {$[17]$} \\
\hline Cytomegalovirus (CMV) status & Higher PTLD-incidence in seronegative patients at transplantation & [19] \\
\hline Immunosupression & $\begin{array}{l}\text { Exact value of single agents unclear, association of PTLD with immunosuppression } \\
\text { is unquestioned }\end{array}$ & \\
\hline Time after transplantation & Highest incidences in the first and third year after transplantation, deceasing thereafter & {$[14]$} \\
\hline \multicolumn{3}{|l|}{ Prognostic factors of PTLD } \\
\hline Age & Younger children have better prognosis & {$[90]$} \\
\hline Localization & $\begin{array}{l}\text { inferior prognosis with involvement of } \\
\text { - bone marrow } \\
\text { - Central nervous sytem (CNS) }\end{array}$ & $\begin{array}{l}{[38]} \\
{[38]}\end{array}$ \\
\hline Histology & $\begin{array}{l}\text { - CD20 expression is associated with good prognosis } \\
\text { - Monomorphic PTLD is associated with inferior prognosis } \\
\text { - T-cell PTLD is associated with poor prognosis } \\
\text { - Burkitt- or Burkitt-like PTLD is associated with poor prognosis }\end{array}$ & $\begin{array}{l}{[91]} \\
{[92]} \\
{[93]} \\
{[38]}\end{array}$ \\
\hline Time after transplantation & Adverse prognosis in patients with late PTLD ( $>1$ year after transplantation; controversial) & {$[14,90]$} \\
\hline Lab parameters & Patients with elevated lactate dehydrogenase (LDH) have inferior prognosis & {$[92]$} \\
\hline Response to treatement & Non-responders to first-line therapy have poor prognosis & [38] \\
\hline
\end{tabular}

PTLD, Post-transplant lymphoproliferative disease

EBV-associated post-transplant smooth muscle tumors

Post-transplant smooth muscle spindle cell tumors (PTSMT) represent a second - very rare - type of EBV-associated tumors after transplantation. To date approximately 70 patients have been reported with PTSMT [40]. About $60 \%$ of PTSMT manifest in kidney transplant patients, approximately $40 \%$ of whom are children, and the tumor occurs significantly earlier in juvenile patients. In general, PTSMT are late complications (median 4 years after transplantation) and are usually slow growing, leiomyoma-like extrauterine tumors that are presumably derived from a myogenous venous wall. A representative example is depicted in Fig. 1b. PTSMT often arise in the donor or recipient liver, the gastrointestinal tract or lungs (usually recipient lungs) and usually spare the uterus/ genitourinary tract. Little is known about the pathophysiology and associated risk factors [40]. However, retrospective data analyses have shown that cerebral tumors are an adverse prognostic factor but not sarcoma-like histology [40].

\section{Treatment}

Reduction of immunosuppression and complete surgical resection are the standard treatment options for PTSMT, while chemotherapy has only been used occasionally [40]. The value of chemotherapy or radiation therapy in unresectable tumors has not been validated; however, in one of the author's experience, post-surgery radiation has been used successfully in a patient with intracranial PTSMT (BMK et al., unpublished results).

Squamous cell carcinoma and basal cell carcinoma

Non-melanoma skin cancer is the most frequently occurring type of cancer in adult long-term survivors of SOT, with squamous cell carcinoma (SCC) and basal cell carcinoma (BCC) representing the predominant histological entities [41]. The incidence of non-melanoma skin cancer approaches $15 \%$ at 15 years post-transplantation [42]. In pediatric SOT patients, few skin cancers arise during childhood and adolescence, but incidences do increase during adulthood [43, 44].

\section{Risk factors}

The frequencies of both SCC and BCC increase with age, length of post-transplant follow-up and sunlight exposure. Patients with a fair skin and those from northern countries are especially at an elevated risk [41]. 
Human papilloma virus (HPV) DNA is frequently detected in SCC specimens of SOT patients. This and the finding that the occurrence of warts after transplantation doubles the risk for SCC [45] has led to the assumption that HPV is involved in the pathogenesis of SCC [46]. However, this hypothesis remains controversial.

Inherited diseases predisposing to cancer (e.g. Fanconi anemia) also play a role in skin cancer pathogenesis in affected individuals [44].

\section{Treatment}

Both BCC and SCC are usually treated by surgery or-in early phases - by cryotherapy alone. Radiotherapy or chemotherapy is only used in patients with advanced disease [47]. Reduction of immunosuppression [47] and a change towards an mTOR-inhibitor (mTOR-I) may be considered to prevent disease recurrence [48].

\section{Prognosis}

Although the majority of patients can be cured from a single lesion, the risk of secondary lesions is high even after complete resection. Multiple lesions are associated with a poor prognosis [47].

\section{Kaposi’s sarcoma}

Post-transplant Kaposi's sarcoma (PT-KS) is a rare entity in northern countries [3], but this disease entity shows high regional variability [49] with much higher incidence rates in the Mediterranean region. In Italy, the incidence rates of PTKS may even exceed the rate of PTLD [50]. Reports on PT$\mathrm{KS}$ are rare in pediatric SOT recipients.

\section{Pathophysiology}

Kaposi's sarcoma-associated herpes virus [KSHV; human herpes virus-8 (HHV-8)] is causative of KS. KSHV is transmitted via infectious saliva, blood and sexual contact. While in low prevalence areas sexual activity is the most frequent transmission route, in high prevalence areas KSHV is often transmitted by non-sexual contact during childhood [49].

Kaposi's sarcoma usually arises in immunocompromised patients, classically those with human immunodeficiency virus (HIV)-related acquired immunodeficiency syndrome (AIDS). Its incidence in the post-transplant population has been found to be elevated by approximately 60 -fold compared to the general population, independent of the study $[3,50]$.

\section{Treatment}

Similar to PTLD, reduction of immunosuppression should be initiated upon diagnosis of PT-KS if possible. Change of immunosuppression towards an mTOR-I-based regimen seems to be even more beneficial than in PTLD. In localized stages, surgical therapy alone may be sufficient to cure PT-KS, while in advanced stages, systemic chemotherapy may be required. Radiotherapy carries a high risk of complications and its use has been discouraged [51].

\section{Prognosis}

Data on prognosis for PT-KS is scarce. Outcome depends on tumor stage and is often poor in advanced disease, while localized disease can be treated efficiently [51].

Anogenital carcinoma

Human papilloma virus infection has been linked to the pathogenesis of anogenital cancers, which include anal cancer, vulvar cancer, penile cancer and cervical cancer $[52,53]$. While incidences of anal, vulvar and penile cancer have been found to be elevated after SOT [3], the risk for cervical cancer was found not to have increased among U.S. SOT recipients, possibly reflecting effective screening and treatment of precancerous lesions [3].

In total, the overall incidences of anogenital carcinoma after SOT are low, falling behind those of KS [3].

\section{Liver cancer}

Although liver cancer risk is elevated among SOT recipients, the increased incidence is largely restricted to liver transplant (LTx) recipients. The latter have an approximately 45 -fold increased risk of liver cancer compared to the general population [3], while the risk is only marginally increased in KTx recipients $[3,6]$. Since LTx is a well-established therapy for liver cancer, the high incidence of this type of cancer after LTx may in part be due to relapse. However, the risk of liver cancer remains slightly elevated even in the long term, possibly due to a contribution of hepatitis B virus (HBV) and hepatitis C virus (HCV) [3].

\section{Gastric cancer}

The distribution of gastric cancer shows large regional differences that are not restricted to the SOT recipient population. While gastric cancer is rather rare in most Western countries, incidences are much higher among residents of Japan and Korea [3, 54]. A three- to eight-fold increase in gastric cancer risk has been reported for KTx recipients in a single center in 
Korea [54]. In some transplant patients, gastric cancer can be associated with EBV [55].

\section{Cancer not associated with viral pathogens}

\section{Kidney cancer}

The incidence of de novo kidney cancer is highly increased after KTx, and the majority of cases occur in the native kidney, sparing the transplanted graft [56]. The excess risk is especially high in young patients (i.e. $>15$-fold elevated compared to the general population [3]). Overall incidences rise with age (from 28 cases/100,000 patient-years in patients transplanted before the age of 34 years, to 407 cases/100,000 patient-years in patients transplanted after their 50th birthday) [3]. The overall incidence in pediatric KTx recipients is $0.6 \%$ in large retrospective studies [4, 57-59].

\section{Histology/classification}

In many studies, all subtypes of primary kidney neoplasia are summarized as "kidney cancer", which is why this is summarized as one entity in this review. The vast majority of "kidney cancer" cases are renal cell carcinomas (RCC) [60]. All cases of "kidney cancer" in pediatric KTx patients reported to date have been RCC $[4,58]$.

\section{Risk factors}

Risk factors for RCC are less extensively studied than those for PTLD. To the authors' best knowledge, data specifically limited to pediatric patients are not available. In adult patients, one of the main risk factors for RCC is chronic kidney disease. Acquired renal cystic disease and a long time on dialysis have been linked to RCC after KTx [59, 61, 62]. Interestingly, the incidences of RCC do not differ significantly between patients on dialysis and patients after KTx, leading to the conclusion that the increased risk is due to chronic renal disease rather than transplantation $[10,63]$.

\section{Therapy and prognosis}

Because most RCC after KTx are limited and asymptomatic at diagnosis, high remission rates are obtained with surgery alone (explantation of the affected kidney or nephronsparing partial kidney resection) [56]. Chemotherapy, immunotherapy and alteration of the immunosuppressive therapy have been discussed, but reports on clinical effectiveness are only anecdotal [56].
Lung cancer

Lung cancer is the second most frequent cancer type in the U.S. general population (following only prostate cancer in men and breast cancer in women). Its slightly elevated risk among KTx recipients therefore accounts for a relevant number of additional patients (115.3 observed vs. 79 expected cases/100,000 patient-years [3]). The reason for this increase is not well studied, but there are hints supporting a permissive role of immunosuppressive medications also in lung cancer pathogenesis.

Lung cancer is, however, a disease of the elderly SOT patient. Incidences are very low before the age of 50 years, but risk increases significantly thereafter [3].

\section{Role of pre-existing cancer}

In the host

In some cases, malignancy after renal transplantation may arise due to relapse of a pre-existing malignant disease in the host or in the donor.

Patients with Wilm's tumor (nephroblastoma) may develop end-stage renal disease following nephrectomy and/or nephrotoxic chemotherapy. To prevent tumor recurrence after potential KTx, an interval of 2 years between the end of treatment and transplantation has been suggested [64]. Although there is some evidence that transplantation even before these 2 years may be safe [65], this is not yet widely accepted [66]. Special attention should be paid to patients with WT-1 mutations (Denys-Drash syndrome) or Frasier syndrome, since carriers of these mutations are at increased risk to develop renal insufficiency as well as nephroblastoma and gonadal tumors $[67,68]$.

Treatment-related end-stage renal disease has been reported after both autologous and allogeneic stem cell transplantation [69]. These patients usually suffer from other severe and complex late complications of their previous treatment and require constant multidisciplinary attention. The cancer risk in these patients (both disease recurrence and secondary malignancy) is probably highly elevated, but quantitative risk estimation is difficult due to very low patient numbers. In rare cases, patients transplanted for cancer-predisposition syndromes (e.g. Fanconi's anemia, Nijmegen breakage syndrome) are at increased risk to develop cancers associated with their underlying disease.

In the donor

Transmission of donor carcinoma is a very rare event [70], and strict preventive measures are undertaken to prevent this. One of these is the exclusion of donors with small solid masses in 
renal grafts. However, transplantation of kidneys with incidental renal cell carcinoma after resection of the renal mass is under discussion for high-risk patients [71]. Still, these attempts must be considered to be highly experimental and may only be applied to selected cases.

\section{Prevention}

Immunosuppressive drugs

Despite general acceptance of the concept of immunosuppression and decreased tumor immunosurveillance being responsible for the increased cancer incidence after SOT, the impact of each individual drug is still controversial and open to discussion. In terms of primary cancer prevention, it is almost impossible to recommend which drug to use - or which one to avoid. One would suggest possibly avoiding the use of OKT3 or thymoglobulin for induction therapy, while other T celldepleting induction regimens do not seem to increase the risk of PTLD [20, 28-30, 32]. Data on the efficacy of mTOR-I, such a rapamycin/sirolimus, in combination with low-dose calcineurin inhibitors in primary cancer prevention are still premature and conflicting, especially in EBV-negative patients $[72,73]$. Therefore, the selection of immunosuppression has to be a trade-off between graft rejection (both acute and chronic) and immunosuppression-induced complications (including malignancies).

For secondary prevention (i.e. prevention of recurrent disease) or as immunosuppression during antineoplastic therapy, several authors have suggested changing to an mTOR-I-based immunosuppressive regimen $[48,74]$ if there is evidence that the mTOR pathway may be activated in this tumor (e.g. PTLD, PTSMT, PT-KS, SCC). Because changing to an mTOR-I based regimen is associated with relevant toxicity [48], it must be balanced against the expected risks on an individual basis.

\section{Vaccination}

Many frequently occurring cancers after SOT are related to viral pathogens, suggesting that vaccination might be an approach to prevent infection with these pathogens and subsequently reduce cancer incidences. Effective vaccination of healthy individuals against HBV (all patients) and HPV (in females) are prototypes of preventative public healthcare programs supporting this idea. However, whether HPV vaccination will succeed in reducing incidences of skin or anogenital cancers after SOT remains to be determined. In stem cell transplant recipients such a mechanism has been suggested [75]. Furthermore, it is controversial whether HPV vaccination should be administered to male patients.

Vaccination against EBV is a very attractive approach to reduce the incidence of EBV-related cancers. However, the development of a protective vaccine remains a long-term vision and is far from being implemented in clinical practice [76]. CMV immunoglobulin given for the prevention of CMV disease was found to be associated with a reduced incidence of PTLD during the first year after transplantation [77]. This effect is not well understood and still awaits confirmation in independent trials.

Treatment of the underlying infection

While treatment of viral hepatitis has proven to provide protective effects on the prevention of hepatocellular carcinoma [78], and $H$. pylori eradication may be able to reduce gastric $H$. pylorirelated cancer [79], data are less promising for other pathogens: treatment of EBV infection with antiviral drugs does not reduce the incidence of PTLD [77]. HPV infection is only treated locally, there are as yet no recommendations for systemic treatment [80].

\section{Lifestyle}

The impact of lifestyle factors on carcinogenesis has been studied mainly in healthy individuals, but resulting recommendations are likely also to be valid for transplant recipients. Of those, exposure to UV sunlight is probably the most relevant risk factor during childhood [44]. Regular use of sunscreen $(\mathrm{SPF}>50)$ has been demonstrated to have a protective effect against SCC and BCC [81]. Moreover, the pediatrician should also advice his adolescent transplant patient about cancer risks associated with smoking and other factors. General risk factors are smoking, adiposities and arterial hypertension for RCC and smoking and alcohol abuse for gastric cancer. Additionally, patients will require information on the prevention of sexually transmitted infections.

\section{Early recognition and screening}

Despite diligent strategies of cancer prevention, the immunosuppressed transplant patient carries an increased risk of cancer development. In the absence of evidence-based screening strategies, which have been explored in prospective cohorts, adjusted screening strategies for cancer after transplantation need to be discussed individually.

\section{Laboratory parameters}

For early recognition of an increased PTLD risk, routine EBV DNA blood load screening has been advocated. However, neither the level nor the time of EBV-positivity in the blood has a prognostic impact on the occurrence of PTLD [16]. A low number of EBV-specific T cells may be correlated with early PTLD development [82], but data are currently too limited to draw definitive conclusions. 
Several soluble serum proteins have recently been associated with the occurrence of PTLD (sCD30, CXCL13, IL-6 and IL-10) [83-85], but their use has not yet found their way into current practice.

\section{Physical examinations}

Patients after KTx should be seen by an experienced dermatologist on a routine basis in order that any form of malignant transformation of skin lesions is recognized early. Harwood and colleagues recently suggested skin cancer surveillance for pediatric patients at 5 and 10 years after transplantation, followed by check-ups at 2-year intervals [86].

Adolescent female transplant recipients should additionally have regular gynecological check-ups with PAP- and HPVscreenings [87], at the latest after sexual activity has commenced. This is also recommended for patients who received HPV vaccination since the effectiveness of the vaccination is unclear during immunosuppression.

For some special high-risk populations, regular gastroscopies to screen for gastric cancer have been proposed [54]. Although this recommendation is mainly relevant for adult KTx recipients from Japan and Korea, gastroscopy should be considered routinely for patients with unexplained upper bowl complaints.

Moreover, a diligent physical examination should be a routine part of the post-transplant follow-up and has to include regular anogenital examinations in order that premalignant or malignant lesions are recognized early. Ultrasound should include remaining host kidneys because they are frequent locations of RCC, and early detection is associated with better survival [88].

\section{Summary}

Patients after KTx carry an increased risk of cancer development, especially those due to infection-related malignancies. During early post-transplantation care, EBV-associated PTLD is the most frequently occurring malignant complication. Other transplant-associated malignancies are rare and typically arise after several years of follow-up. Some of these have preventable risk factors (e.g. sun exposure, smoking, alcohol), which should be addressed by the pediatric transplant physician during childhood and adolescence.

There is ongoing discussion about optimal recommendations for cancer prevention and surveillance after pediatric $\mathrm{KTx}$, and consensus recommendations are currently not available. The following guidelines should be considered for every patient:

- Consider PTLD in unexplained illness, especially early after transplantation and when the patient was EBV-naïve before transplantation and/or if he/she has reactivated EBV after transplant.

- Vaccination for HBV and HPV should be performed according to the recommendations for healthy children.

- Lifestyle counseling in regard to risk factors for late cancer development should be part of the posttransplant follow-up routine.

- Patients should be encouraged to have regular examinations of skin and anogenital region by dermatologists and gynecologists.

\section{Multiple choice questions (answers are provided following the reference list)}

1. Which of the following is true?

a) The spectrum of cancer is the same among pediatric and adult solid organ transplant (SOT) recipients

b) Post-transplant lymphoproliferative disease (PTLD) is the most frequent malignancy after pediatric SOT

c) The 5-year incidence rate of PTLD is $5-10 \%$ in pediatric kidney transplant (KTx) recipients

d) Gastric cancer is especially high in patients from Mediterranean countries

e) PTLD is the only known Epstein-Barr virus (EBV)related malignancy

2. Which of the following malignant diseases is not related to infectious pathogens?
a) PTLD
b) Kaposi's sarcoma (KS)
c) Renal cell carcinoma (RCC)
d) Hepatocellular carcinoma (HCC)
e) Vulvar cancer

3. The risk of developing PTLD in pediatric KTx patients is increased for patients:

a) EBV-seronegative at transplantation

b) Beyond 5 years after transplantation

c) Receiving living-related grafts

d) After hemodialysis

e) None of the above

4. Which regular follow-up analysis is not recommended for a standard follow-up cancer screening program after pediatric SOT?
a) Gastroscopy
b) EBV-PCR
c) Regular presentation to dermatologist
d) Regular presentation to gynaecologist (female patients only)
e) Regular presentation to transplant physician 
5. Which of the following malignant diseases has an increased incidence after SOT?
a) Squamous cell carcinoma
b) Lung carcinoma
c) Renal cell carcinoma
d) Lip carcinoma
e) All of the above

Acknowledgments The authors thank Lars Pape, Hannover Medical School for helpful critical discussion of the manuscript. This work was in part supported by the Integrated Research and Treatment Center Transplantation (IFB-Tx, MM and BMK) financed by a grant from the German Federal Ministry of Education and Research [grant number: 01EO0802] and the German Children's Cancer Foundation (BMK).

\section{References}

1. Smith JM, Martz K, Blydt-Hansen TD (2013) Pediatric kidney transplant practice patterns and outcome benchmarks, 1987-2010: a report of the North American Pediatric Renal Trials and Collaborative Studies. Pediatr Transplant 17:149-157

2. Samuel SM, Tonelli MA, Foster BJ, Alexander RT, Nettel-Aguirre A, Soo A, Hemmelgarn BR; Pediatric Renal Outcomes Canada Group (2011) Survival in pediatric dialysis and transplant patients. Clin J Am Soc Nephrol 6:1094-1099

3. Engels EA, Pfeiffer RM, Fraumeni JF Jr, Kasiske BL, Israni AK, Snyder JJ, Wolfe RA, Goodrich NP, Bayakly AR, Clarke CA, Copeland G, Finch JL, Fleissner ML, Goodman MT, Kahn A, Koch L, Lynch CF, Madeleine MM, Pawlish K, Rao C, Williams MA, Castenson D, Curry M, Parsons R, Fant G, Lin M (2011) Spectrum of cancer risk among US solid organ transplant recipients. JAMA 306:1891-1901

4. Simard JF, Baecklund E, Kinch A, Brattström C, Ingvar Å, Molin D, Adami J, Fernberg P, Wilczek H, Ekbom A, Smedby KE (2011) Pediatric organ transplantation and risk of premalignant and malignant tumors in Sweden. Am J Transplant 11:146-151

5. Collett D, Mumford L, Banner NR, Neuberger J, Watson C (2010) Comparison of the incidence of malignancy in recipients of different types of organ: A UK Registry audit. Am J Transplant 10:1889-1896

6. Piselli P, Serraino D, Segoloni GP, Sandrini S, Piredda GB, Scolari MP, Rigotti P, Busnach G, Messa P, Donati D, Schena FP, Maresca MC, Tisone G, Veroux M, Sparacino V, Pisani F, Citterio F (2013) Risk of de novo cancers after transplantation: Results from a cohort of 7217 kidney transplant recipients, Italy 1997-2009. Eur J Cancer 49:336-344

7. Vajdic CM, McDonald SP, McCredie MR, van Leeuwen MT, Stewart JH, Law M, Chapman JR, Webster AC, Kaldor JM, Grulich AE (2006) Cancer incidence before and after kidney transplantation. JAMA 296:2823-2831

8. Adami J, Gabel H, Lindelof B, Ekstrom K, Rydh B, Glimelius B, Ekbom A, Adami HO, Granath F (2003) Cancer risk following organ transplantation: a nationwide cohort study in Sweden. Br J Cancer 89:1221-1227

9. Villeneuve PJ, Schaubel DE, Fenton SS, Shepherd FA, Jiang Y, Mao Y (2007) Cancer Incidence Among Canadian Kidney Transplant Recipients. Am J Transplant 7:941-948

10. Grulich AE, van Leeuwen MT, Falster MO, Vajdic CM (2007) Incidence of cancers in people with HIV/AIDS compared with immunosuppressed transplant recipients: a meta-analysis. Lancet 370:59-67
11. Cohen AH, Sweet SC, Mendeloll E, Mallory GB, Huddleston CB, Kraus M, Kelly M, Hayashi R, DeBaun MR (2000) High Incidence of Posttransplant Lymphoproliferative Disease in Pediatric Patients with Cystic Fibrosis. Am J Respir Crit Care Med 161:1252-1255

12. Elidemir O, Kancherla BS, Schecter MG, McKenzie ED, Morales DL, Heinle JS, Mallory GB (2009) Post-transplant lymphoproliferative disease in pediatric lung transplant recipients: Recent advances in monitoring. Pediatr Transplant 13:606-610

13. Quintini C, Kato T, Gaynor JJ, Ueno T, Selvaggi G, Gordon P, McLaughlin G, Tompson J, Ruiz P, Tzakis A (2006) Analysis of risk factors for the development of posttransplant lymphoprolipherative disorder among 119 children who received primary intestinal transplants at a single center. Transplant Proc 38:1755-1758

14. Schober T, Framke T, Kreipe H, Schulz TF, Grohennig A, Hussein K, Baumann U, Pape L, Schubert S, Wingen AM, Jack T, Koch A, Klein C, Maecker-Kolhoff B (2013) Characteristics of early and late PTLD development in pediatric solid organ transplant recipients. Transplantation 95:240-246

15. Thorley-Lawson DA, Gross A (2004) Persistence of the EpsteinBarr Virus and the origins of associated lymphomas. N Engl J Med 350:1328-1337

16. Höcker B, Fickenscher H, Delecluse H-J, Böhm S, Küsters U, Schnitzler P, Pohl M, John U, Kemper MJ, Fehrenbach H, Wigger M, Holder M, Schröder M, Billing H, Fichtner A, Feneberg R, Sander A, Köpf-Shakib S, Süsal C, Tönshoff B (2013) Epidemiology and morbidity of Epstein-Barr virus infection in pediatric renal transplant recipients: A multicenter, prospective study. Clin Infect Dis 56:84-92

17. Chinnock R, Webber SA, Dipchand AI, Brown RN, George JF; The Pediatric Heart Transplant Study (2012) A 16-year multi-institutional study of the role of age and EBV status on PTLD incidence among pediatric heart transplant recipients. Am J Transplant 12:3061-3068

18. Dharnidharka VR, Lamb KE, Gregg JA, Meier-Kriesche HU (2012) Associations Between EBV serostatus and organ transplant type in PTLD risk: An analysis of the SRTR National Registry Data in the United States. Am J Transplant 12:976-983

19. Opelz G, Daniel V, Naujokat C, Dohler B (2009) Epidemiology of pretransplant EBV and CMV serostatus in relation to posttransplant non-Hodgkin lymphoma. Transplantation 88:962-967

20. Opelz G, Döhler B (2004) Lymphomas after solid organ transplantation: A collaborative transplant study report. Am J Transplant 4:222230

21. Dharnidharka VR, Sullivan EK, Stablein DM, Tejani AH, Harmon WE (2001) Risk factors for posttransplant lymphoproliferative disorder (PTLD) in pediatric kidney transplantation: a report of the North American Pediatric Renal Transplant Cooperative Study (NAPRTCS). Transplantation 71:1065-1068

22. Opelz G, Dohler B (2010) Pediatric kidney transplantation: analysis of donor age, HLA match, and posttransplant non-Hodgkin lymphoma: a collaborative transplant study report. Transplantation 90:292297

23. Manlhiot C, Pollock-BarZiv SM, Holmes C, Weitzman S, Allen U, Clarizia NA, Ngan B-Y, McCrindle BW, Dipchand AI (2010) Posttransplant lymphoproliferative disorder in pediatric heart transplant recipients. J Heart Lung Transplant 29:648-657

24. O’Neill JO, Edwards LB, Taylor DO (2006) Mycophenolate mofetil and risk of developing malignancy after orthotopic heart transplantation: Analysis of the transplant registry of the International Society for Heart and Lung Transplantation. J Heart Lung Transplant 25: 1186-1191

25. Funch DP, Ko HH, Travasso J, Brady J, Kew CE 2nd, Nalesnik MA, Walker AM (2005) Posttransplant lymphoproliferative disorder among renal transplant patients in relation to the use of mycophenolate mofetil. Transplantation 80:1174-1180

26. Robson R, Cecka JM, Opelz G, Budde M, Sacks S (2005) Prospective registry-based observational sohort study of the long- 
term risk of malignancies in renal transplant patients treated with mycophenolate mofetil. Am J Transplant 5:2954-2960

27. Grinyo J, Charpentier B, Pestana JM, Vanrenterghem Y, Vincenti F, Reyes-Acevedo R, Apanovitch AM, Gujrathi S, Agarwal M, Thomas D, Larsen CP (2010) An integrated safety profile analysis of belatacept in kidney transplant recipients. Transplantation 90:15211527

28. Kremers WK, Devarbhavi HC, Wiesner RH, Krom RAF, Macon WR, Habermann TM (2006) Post-transplant lymphoproliferative disorders following liver transplantation: Incidence, risk factors and survival. Am J Transplant 6:1017-1024

29. Caillard S, Dharnidharka V, Agodoa L, Bohen E, Abbott K (2005) Posttransplant lymphoproliferative disorders after renal transplantation in the United States in era of modern immunosuppression. Transplantation 80:1233-1243

30. Opelz G, Naujokat C, Daniel V, Terness P, Dohler B (2006) Disassociation between risk of graft loss and risk of non-Hodgkin lymphoma with induction agents in renal transplant recipients. Transplantation 81:1227-1233

31. Chapman TM, Keating GM (2003) Basiliximab: a review of its use as induction therapy in renal transplantation. Drugs 63:2803-2835

32. Kirk AD, Cherikh WS, Ring M, Burke G, Kaufman D, Knechtle SJ, Potdar S, Shapiro R, Dharnidharka VR, Kauffman HM (2007) Dissociation of depletional induction and posttransplant lymphoproliferative disease in kidney recipients treated with alemtuzumab. Am J Transplant 7:2619-2625

33. Swerdlow SH, Campo E, Harris NL, Jaffe ES, Pileri SA, Stein H, Thiele J, Vardiman JW (2008) WHO Classification of tumours of haematopoietic and lymphoid tissues, 4th edn. World Health Organization, Geneva

34. Tsai DE, Hardy CL, Tomaszewski JE, Kotloff RM, Oltoff KM, Somer BG, Schuster SJ, Porter DL, Montone KT, Stadtmauer EA (2001) Reduction in immunosuppression as initial therapy for posttransplant lymphoproliferative disorder: analysis of prognostic variables and long-term follow-up of 42 adult patients. Transplantation 71:1076-1088

35. Parker A, Bowles K, Bradley JA, Emery V, Featherstone C, Gupte G, Marcus R, Parameshwar J, Ramsay A, Newstead C (2010) Management of post-transplant lymphoproliferative disorder in adult solid organ transplant recipients-BCSH and BTS Guidelines. Br J Haematol 149:693-705

36. Gross TG, Orjuela MA, Perkins SL, Park JR, Lynch JC, Cairo MS, Smith LM, Hayashi RJ (2012) Low-dose chemotherapy and rituximab for posttransplant lymphoproliferative disease (PTLD): A Children's Oncology Group report. Am J Transplant 12:3069-3075

37. Bollard CM, Rooney CM, Heslop HE (2012) T-cell therapy in the treatment of post-transplant lymphoproliferative disease. Nat Rev Clin Oncol 9:510-519

38. Maecker B, Jack T, Zimmermann M, Abdul-Khaliq H, Burdelski M, Fuchs A, Hoyer P, Koepf S, Kraemer U, Laube GF, Muller-Wiefel DE, Netz H, Pohl M, Toenshoff B, Wagner HJ, Wallot M, Welte K, Melter M, Offner G, Klein C (2007) CNS or bone marrow involvement as risk factors for poor survival in post-transplantation lymphoproliferative disorders in children after solid organ transplantation. J Clin Oncol 25:4902-4908

39. Webber SA, Naftel DC, Fricker FJ, Olesnevich P, Blume ED, Addonizio L, Kirklin JK, Canter CE (2006) Lymphoproliferative disorders after paediatric heart transplantation: a multi-institutional study. Lancet 367:233-239

40. Jonigk D, Laenger F, Maegel L, Izykowski N, Rische J, Tiede C, Klein C, Maecker-Kolhoff B, Kreipe H, Hussein K (2012) Molecular and clinicopathological analysis of Epstein-Barr virus-associated posttransplant smooth muscle tumors. Am J Transplant 12:19081917

41. Mudigonda T, Levender MM, O'Neill JL, West CE, Pearce DJ, Feldman SR (2013) Incidence, risk factors, and preventative management of skin cancers in organ transplant recipients: a review of single- and multicenter retrospective studies from 2006 to 2010. Dermatol Surg 39:345-364

42. Tessari G, Naldi L, Boschiero L, Minetti E, Sandrini S, Nacchia F, Valerio F, Rugiu C, Sassi F, Gotti E, Fonte L, Talamini G, Girolomoni G (2013) Incidence of primary and second cancers in renal transplant recipients: A multicenter cohort study. Am J Transplant 13:214-221

43. Penn I (1998) De novo malignances in pediatric organ transplant recipients. Pediatr Transplant 2:56-63

44. Euvrard S, Kanitakis J, Cochat P, Claudy A (2004) Skin cancers following pediatric organ transplantation. Dermatol Surg 30:616-621

45. Comeau S, Jensen L, Cockfield SM, Sapijaszko M, Gourishankar S (2008) Non-melanoma skin cancer incidence and risk factors after kidney transplantation: a Canadian experience. Transplantation 86: 535-541

46. Arnold AW, Hofbauer GF (2012) Human papillomavirus and squamous cell cancer of the skin-epidermodysplasia verruciformisassociated human papillomavirus revisited. Curr Probl Dermatol 43:49-56

47. Euvrard S, Kanitakis J, Claudy A (2003) Skin cancers after organ transplantation. N Engl J Med 348:1681-1691

48. Euvrard S, Morelon E, Rostaing L, Goffin E, Brocard A, Tromme I, Broeders N, del Marmol V, Chatelet V, Dompmartin A, Kessler M, Serra AL, Hofbauer GFL, Pouteil-Noble C, Campistol JM, Kanitakis J, Roux AS, Decullier E, Dantal J (2012) Sirolimus and secondary skin-cancer prevention in kidney transplantation. N Engl J Med 367: 329-339

49. Hosseini-Moghaddam SM, Soleimanirahbar A, Mazzulli T, Rotstein C, Husain S (2012) Post renal transplantation Kaposi's sarcoma: a review of its epidemiology, pathogenesis, diagnosis, clinical aspects, and therapy. Transplant Infect Dis 14:338-345

50. Pedotti P, Cardillo M, Rossini G, Arcuri V, Boschiero L, Caldara R, Cannella G, Dissegna D, Gotti E, Marchini F, Maresca MC, Montagnino G, Montanaro D, Rigotti P, Sandrini S, Taioli E, Scalamogna M (2003) Incidence of cancer after kidney transplant: results from the North Italy transplant program. Transplantation 76: $1448-1451$

51. Riva G, Luppi M, Barozzi P, Forghieri F, Potenza L (2012) How I treat HHV8/KSHV-related diseases in posttransplant patients. Blood 120:4150-4159

52. Gormley RH, Kovarik CL (2012) Human papillomavirus-related genital disease in the immunocompromised host: Part I. J Am Acad Dermatol 66:867.e1-14; quiz 881-882. doi:10.1016/j.jaad.2010.12. 050

53. Pietrzak B, Mazanowska N, Ekiel AM, Durlik M, Martirosian G, Wielgos M, Kaminski P (2012) Prevalence of high-risk human papillomavirus cervical infection in female kidney graft recipients: an observational study. Virol J 9:117

54. Lee I-S, Kim T-H, Kim Y-H, Yook J-H, Kim B-S, Han D-J (2012) Clinical significance of gastric cancer surveillance in renal transplant recipients. World J Surg 36:1806-1810

55. Au WY, Pang A, Chan EC, Chu KM, Shek TW, Kwong YL (2005) Epstein-barr virus-related gastric adenocarcinoma: an early secondary cancer post hemopoietic stem cell transplantation. Gastroenterology 129:2058-2063

56. Tsaur I, Obermüller N, Jonas D, Blaheta R, Juengel E, Scheuermann E-H, Kachel H-G, Karalis A, Probst M (2011) De novo renal cell carcinoma of native and graft kidneys in renal transplant recipients. BJU Int 108:229-234

57. Debray D, Baudouin V, Lacaille F, Charbit M, Rivet C, Harambat J, Iserin F, Di Filippo S, Guyot C (2009) De novo malignancy after solid organ transplantation in children. Transplant Proc 41:674-675

58. Koukourgianni F, Harambat J, Ranchin B, Euvrard S, Bouvier R, Liutkus A, Cochat P (2010) Malignancy incidence after renal transplantation in children: a 20-year single-centre experience. Nephrol Dial Transplant 25:611-616 
59. Hurst FP, Jindal RM, Graham LJ, Falta EM, Ea E, Stackhouse GB, Agodoa LY, Lentine KL, Salifu MO, Abbott KC (2010) Incidence, predictors, costs, and outcome of renal cell carcinoma after kidney transplantation: USRDS experience. Transplantation 90:898-904

60. Ljungberg B, Campbell SC, Cho HY, Jacqmin D, Lee JE, Weikert S, Kiemeney LA (2011) The epidemiology of renal cell carcinoma. Eur Urol 60:615-621

61. Schwarz A, Vatandaslar S, Merkel S, Haller H (2007) Renal cell carcinoma in transplant recipients with acquired cystic kidney disease. Clin J Am Soc of Nephrol 2:750-756

62. Wong G, Turner RM, Chapman JR, Howell M, Lim WH, Webster AC, Craig JC (2013) Time on dialysis and cancer risk after kidney transplantation. Transplantation 95:114-121

63. Stewart JH, Vajdic CM, van Leeuwen MT, Amin J, Webster AC, Chapman JR, McDonald SP, Grulich AE, McCredie MRE (2009) The pattern of excess cancer in dialysis and transplantation. Nephrol Dial Transplant 24:3225-3231

64. Transplantation EEGoR (2002) European best practice guidelines for renal transplantation. Section IV: Long-term management of the transplant recipient. IV.11 Paediatrics (specific problems). Nephrol Dial Transplant 17[Suppl 4]:55-58

65. Grigoriev Y, Lange J, Peterson SM, Takashima JR, Ritchey ML, Ko D, Feusner JH, Shamberger RC, Green DM, Breslow NE (2012) Treatments and outcomes for end-stage renal disease following Wilms tumor. Pediatr Nephrol 27:1325-1333

66. Querfeld U, Stefanidis CJ (2012) Pediatrics: When should children surviving a Wilms tumor be transplanted? Nat Rev Nephrol 8:443444

67. Auber F, Jeanpierre C, Denamur E, Jaubert F, Schleiermacher G, Patte C, Cabrol S, Leverger G, Nihoul-Fekete C, Sarnacki S (2009) Management of Wilms tumors in Drash and Frasier syndromes. Pediatr Blood Cancer 52:55-59

68. Patel PR, Pappas J, Arva NC, Franklin B, Brar PC (2013) Early presentation of bilateral gonadoblastomas in a Denys-Drash syndrome patient: a cautionary tale for prophylactic gonadectomy. J Pediatr Endocrinol Metab 9:1-4

69. Beitinjaneh A, Burns LJ, Majhail NS (2010) Solid organ transplantation in survivors of hematopoietic cell transplantation: a single institution case series and literature review. Clin Transplant 24: E94-102

70. Desai R, Collett D, Watson CJ, Johnson P, Evans T, Neuberger J (2012) Cancer transmission from organ donors-unavoidable but low risk. Transplantation 94:1200-1207

71. Sener A, Uberoi V, Bartlett ST, Kramer AC, Phelan MW (2009) Living-donor renal transplantation of grafts with incidental renal masses after ex-vivo partial nephrectomy. BJU Int 104:1655-1660

72. Pape L, Lehner F, Blume C, Ahlenstiel T (2011) Pediatric kidney transplantation followed by de novo therapy with everolimus, lowdose cyclosporine A, and steroid elimination: 3-year data. Transplantation 92:658-662

73. Sampaio MS, Cho YW, Shah T, Bunnapradist S, Hutchinson IV (2012) Association of immunosuppressive maintenance regimens with posttransplant lymphoproliferative disorder in kidney transplant recipients. Transplantation 93:73-81

74. Pascual J (2007) Post-transplant lymphoproliferative disorder-the potential of proliferation signal inhibitors. Nephrol Dial Transplant 22:i27-i35

75. Savani BN, Goodman S, Barrett AJ (2009) Can routine posttransplant HPV vaccination prevent commonly cccurring epithelial cancers after allogeneic stem cell transplantation? Clin Cancer Res 15:2219-2221

76. Cohen JI, Fauci AS, Varmus H, Nabel GJ (2011) Epstein-Barr virus: An important vaccine target for cancer prevention. Sci Transl Med 2;3:107fs107. doi:10.1126/scitranslmed.300287

77. Opelz G, Daniel V, Naujokat C, Fickenscher H, Dohler B (2007) Effect of cytomegalovirus prophylaxis with immunoglobulin or with antiviral drugs on post-transplant non-Hodgkin lymphoma: a multicentre retrospective analysis. Lancet Oncol 8: 212-218

78. Ueno Y, Sollano JD, Farrell GC (2009) Prevention of hepatocellular carcinoma complicating chronic hepatitis C. J Gastroenterol Hepatol 24:531-536

79. Fuccio L, Zagari RM, Eusebi LH, Laterza L, Cennamo V, Ceroni L, Grilli D, Bazzoli F (2009) Meta-analysis: Can Helicobacter pylori eradication treatment reduce the risk for gastric cancer? Ann Intern Med 151:121-128

80. Hathaway JK (2012) HPV: diagnosis, prevention, and treatment. Clin Obstet Gynecol 55:671-680

81. Ulrich C, Jurgensen JS, Degen A, Hackethal M, Ulrich M, Patel MJ, Eberle J, Terhorst D, Sterry W, Stockfleth E (2009) Prevention of non-melanoma skin cancer in organ transplant patients by regular use of a sunscreen: a 24 months, prospective, case-control study. Br J Dermatol 161[Suppl 3]:78-84

82. Wilsdorf N, Eiz-Vesper B, Henke-Gendo C, Diestelhorst J, Oschlies I, Hussein K, Pape L, Baumann U, Tonshoff B, Pohl M, Hocker B, Wingen AM, Klapper W, Kreipe H, Schulz TF, Klein C, MaeckerKolhoff B (2013) EBV-specific T-cell immunity in pediatric solid organ graft recipients with posttransplantation lymphoproliferative disease. Transplantation 95:247-255

83. Hinrichs C, Wendland S, Zimmermann H, Eurich D, Neuhaus R, Schlattmann P, Babel N, Riess H, Gärtner B, Anagnostopoulos I, Reinke P, Trappe RU (2011) IL-6 and IL-10 in post-transplant lymphoproliferative disorders development and maintenance: a longitudinal study of cytokine plasma levels and T-cell subsets in 38 patients undergoing treatment. Transpl Int 24:892-903

84. Schiffer L, Henke-Gendo C, Wilsdorf N, Hussein K, Pape L, Schmitt C, Haller H, Schiffer M, Klein C, Kreipe H, Maecker-Kolhoff B (2012) CXCL13 as a novel marker for diagnosis and disease monitoring in pediatric PTLD. Am J Transplant 12:1610-1617

85. Haque T, Chaggar T, Schafers J, Atkinson C, McAulay KA, Crawford DH (2011) Soluble CD30: a serum marker for EpsteinBarr virus-associated lymphoproliferative diseases. J Med Virol 83: 311-316

86. Harwood CA, Mesher D, McGregor JM, Mitchell L, Leedham-Green M, Raftery M, Cerio R, Leigh IM, Sasieni P, Proby CM (2013) A surveillance model for skin cancer in organ transplant recipients: A 22-year prospective study in an ethnically diverse population. Am J Transplant 13:119-129

87. Pietrzak B, Bobrowska K, Szpotanska-Sikorska M, JabiryZieniewicz Z, Kociszewska-Najman B, Durlik M, Kaminski P, Wielgos M (2011) Multiple types of high-risk human papilloma virus in the lower genital tract of a female kidney recipient: A case report. Transplant Proc 43:2994-2996

88. Ishikawa I, Honda R, Yamada Y, Kakuma T (2004) Renal cell carcinoma detected by screening shows better patient survival than that detected following symptoms in dialysis patients. Ther Apher Dial 8:468-473

89. Pinho-Apezzato ML, Tannuri U, Tannuri ACA, Mello ES, Lima F, Gibelli NE, Santos MM, Ayoub AA, Maksoud-Filho JG, Velhote MC, Silva MM, Andrade WC, Miyatani HT (2010) Multiple clinical presentations of lymphoproliferative disorders in pediatric liver transplant recipients: A single-center experience. Transplant Proc 42: $1763-1768$

90. Dharnidharka VR, Martz KL, Stablein DM, Benfield MR (2011) Improved survival with recent post-transplant lymphoproliferative disorder (PTLD) in children with kidney transplants. Am J Transplant 11:751-758

91. Orjuela MA, Alobeid B, Liu X, Siebert AL, Kott ER, Addonizio LJ, Morris E, Garvin JH, Lobritto SJ, Cairo MS (2011) CD20 expression predicts survival in paediatric post-transplant lymphoproliferative disease (PTLD) following solid organ transplantation. Br J Haematol 152:733-742 
92. Caillard S, Porcher R, Provot F, Dantal J, Choquet S, Durrbach A, Morelon E, Moal V, Janbon B, Alamartine E, Pouteil Noble C, Morel D, Kamar N, Buchler M, Mamzer MF, Peraldi MN, Hiesse C, Renoult E, Toupance O, Rerolle JP, Delmas S, Lang P, Lebranchu Y, Heng AE, Rebibou JM, Mousson C, Glotz D, Rivalan J, Thierry A, Etienne I, Moal MC, Albano L, Subra JF, Ouali N, Westeel PF, Delahousse M, Genin R, Hurault de Ligny B, Moulin B (2013) Posttransplantation lymphoproliferative disorder after kidney transplantation: report of a nationwide French registry and the development of a new prognostic score. J Clin Oncol 31:1302-1309

93. Tiede C, Maecker-Kolhoff B, Klein C, Kreipe H, Hussein K (2013) Risk factors and prognosis in T-cell posttransplantation lymphoproliferative diseases: reevaluation of 163 cases. Transplantation 95:479-488

\section{Answers}

$1: \mathrm{b}$

2: c

3: a

4: a

5: e 